\title{
New records of wood inhabiting fungal species from Kondapalli reserved forest of Central Eastern Ghats, India
}

\author{
Praveen Kumar Nagadesi ${ }^{1^{*}}$ \& Venkatesh Rampilla ${ }^{2}$ \\ ${ }^{1}$ Department of Botany, Post graduate and Research Center, St. Joseph's College (Autonomous), Lalbagh Road, Bangalore 560 027, Karnataka, \\ India \\ ${ }^{2}$ Department of Botany, Dr. L.H.R. Govt. Degree College, Mylavaram 521 230, Krishna district, Andhra Pradesh, India \\ *Email: nagadesipraveenkumar@yahoo.com
}

\section{ARTICLE HISTORY}

Received: 01 March 2021

Accepted: 08 June 2021

Available online: 10 July 2021

\section{KEYWORDS}

Wood inhabiting fungi Kondapalli

Central Eastern Ghats

Artomyces microsporus

Hymenochaetopsis rigidula

\section{ABSTRACT}

Wood inhabiting fungi that grow specifically on leaf litter, wood debris, humus rich soil of forest helps in biodegradation and increase soil fertility. The fruiting bodies of fungi were collected from partially dead forest trees, fallen wooden logs, leaf litter and decomposing humus rich soil of Kondapalli forest area, Central Eastern Ghats of India. Detailed macroscopic and microscopic study of collected fungal samples revealed the occurrence of wood inhabiting fungi belonging to 7 genera and 9 species; i.e. Geastrum triplex Jungh., Marasmius siccus (Schweinitz) Fries, M. fulvoferrugineus Gilliam, M. oreades (Bolt.: Fries) Fries Epicr. Lactarius piperatus (L.) Pers., Flammulina velutipes (Curtis) Singer, Artomyces microsporus (Qiu X. Wu \& R. H. Petersen) Lickey, Hymenochaetopsis rigidula (Berk. \& M. A. Curtis) S. H. He \& Jiao Yang and Bjerkandera adusta (Willd: Fr.) Karst. For the first time, A. microsporus (Qiu X. Wu \& R. H. Petersen) Lickey and H. rigidula (Berk. \& M. A. Curtis) S. H. He \& Jiao Yang., were reported from India. M. fulvoferrugineus Gilliam was reported second time from India. The wood inhabiting fungi were new records to Kondapalli forest area, Central Eastern Ghats of India.

\section{Introduction}

About one billion years ago, the Kingdom Mycota becomes an independent eukaryotic line under evolution (1). In the world about 1.5 - 5.1 million fungi have been estimated by mycologists (2). Out of which, about one lakh fungi were described and the available numbers of fungal species in the entire world was not very well known (3). Giving names to fungi was the key of knowledge gaining (4). Morphological identification of fungi was highly difficult in case of non-sporulating fungi (5). So morphology based identification was overruled by modern molecular systems; this uses molecular study of DNA sequence; resolves major taxonomical problems, and evolutionary relationship among fungi $(6,7)$. This is the time to combine both morphological and molecular taxonomy, to solve the taxonomical problems, to utilize it in classification systems, evolution and past evolutionary relationships among fungi.

Wood-inhabiting fungi were an ecologically, economically, pharmacologically, medicinally and industrially important group of higher basidiomycetous macroscopic forms. The tropical region was hosting the highest mycodiversity has been inadequately sampled by mycologists and the mycoflora was scarcely documented $(8,9)$. The tropical country like Indian the mycodiversity literature shows the reports (10) on the investigations on the diversity of wood inhabiting fungi in Sarkaghat region of district Mandi, Himachal Pradesh, NorthWestern Himalaya, India. Two species of brown rot causing wood decaying polypores observed in the forests of Western Maharashtra, India were Daedalea africana and D. quercina (11). The applied aspects of wood inhabiting fungi were explained (12). The reports for wood inhabiting fungi from Krishna district, Andhra Pradesh is lacking. In this line, only few works had been conducted $(14,16)$.

In India, the Eastern Ghats spread about 75000 Sq. $\mathrm{km}$ of area, with $200 \mathrm{~km}$ width in North and 100 $\mathrm{km}$ width in the South. In the $15^{\circ} 43^{\prime}$ and $17^{\circ} 10^{\prime}$ north latitude and $80^{\circ} 00^{\prime}$ and $81^{\circ} 33^{\prime}$ east longitude, the Central Eastern Ghats of Andhra Pradesh is situated (13). In between Northern and Central Eastern Ghats, the Kondapalli forest area of Krishna district, Andhra Pradesh, is situated with diverse of flora and fauna (14). The forest occupies $9 \%$ of the total district area i.e. 30000 acres as deciduous forest with the scrub infringes (14). The Kondapalli bhommallu also called Kondapalli toys has been made from Tella poniki

(c) Nagadesi \& Rampilla (2021). This is an open-access article distributed under the terms of the Creative Commons Attribution License, which permits unrestricted use, distribution and reproduction in any medium, provided the original author and source are credited (https://creativecommons.org/licenses/by/4.0/). 
wood (15). The present study aims at the phenotypical identification of wood inhabiting fungi from the Eastern Ghats of South India.

\section{Materials and Methods}

\section{Phenotypical identification}

The tropical forest of Kondapalli is one of the preserved forests in the Krishna district; which covers $120 \mathrm{~km}^{2}$ area was protected by Andhra Pradesh Forest Department. (14). A survey was conducted in different seasons of 2017 to 2019, and different wood inhabiting fungi was collected in clean polythene bags and brought to the lab for phenotypical identification. The fungal bodies were examined for morphological characters based on the standard method $(14,16,17)$.

\section{Results and Discussion}

Out of 50 wood inhabiting fungi collected, nine was identified and all wood inhabiting fungi were new records to Kondapalli forest area. For the first time, A. microsporus (Qiu X. Wu \& R. H. Petersen), Lickey and $H$. rigidula (Berk. \& M. A. Curtis) S. H. He \& Jiao Yang, were reported from India. The detailed description of the wood inhabiting fungi is given below.

Artomyces microsporus (Qiu X. Wu \& R. H. Petersen) Lickey, in Lickey, Hughes \& Petersen, Sydowia 55: 227 (2003).

Fruiting body is fragmented; the largest one is $6.5 \mathrm{~cm}$ in length $\mathrm{x} 3.2 \mathrm{~cm}$ in wide, profusely branched, yellowish white. Branches forming to 7 ranks, 4 to 6 per node, unequal, up to $2 \mathrm{~mm}$ in diameter ( Fig. 2-E); Tips of upper surface coronate-cristate, pale ochraceous buff and pale pinkish cinnamon; Hymenium surface of dried specimen ochraceous buff, apices cinnamon rufous (Fig. 2-F). No conspicuous stalk present, apparently branched from base; basal mycelialpad taned. Hyphal system monomitic; Context composed of generative hyphae, thin walled, often inflated, clamped; Basidia 16.45 22.86 long x $4.0-4.8 \mu \mathrm{m}$ wide, clamped, one to two spores observed. Basidiospores broadly ellipsoid 4.2 x $2.8 \mu \mathrm{m}$ in size, amyloid, minutely asperulate, often guttulate. Gloeoplerous hyphae, common, up to 6.25 $\mu \mathrm{m}$ diameter, aseptate. Gloeocystidia cylindrical, 2.8 $\mathrm{x} 4.4 \mu \mathrm{m}$ wide, non emergent to protruding to $4 \mu \mathrm{m}$. Taste weakly acrid.

\section{Collection examined}

On humus rich soil of Kondapalli forest, Andhra Pradesh, India. Collected by N. Praveen Kumar, Accession no: ALCKP 43, 12 - 8- 2017.

\section{Bjerkandera adusta (Willd.:Fr.) Karst. Meddn Soc. Fauna Flora Fenn. 5: 38. 1879.}

Fruiting body is annual, effuse - reflexed, sessile, forms thin, leathery brackets one above the other, 2.2 - 8.5 × $2.5-4.8$ × $0.6 \mathrm{~cm}$; upper surface grayish to white, tomentose when young at maturity glabrous, often uneven, zonated; margin irregular, whitish when young; Hymenium surface gray coloured, finely pored (Fig. 3-C), microscopic, $5-7$ per mm, round, grey when young, blackish with age; tube layer $2.5 \mathrm{~mm}$ deep; Hyphal system monomitic; hyphae with abundant clamp connections. Context is $1.5-3.2 \mathrm{~mm}$ thick, tough, leathery, creamish yellow, lacking a black line in tube layer. Basidiospores elliptical, inamyloid, smooth, $4.24-6.25 \times 2.5-3.5$ $\mu \mathrm{m}$ in size, in Potassium hydroxide hyaline; Setae absent. Cystidia absent; slightly astringent smell.

\section{Collection examined}

On dead branch of hardwoods of Kondapalli forest, Andhra Pradesh, India. Collected by N. Praveen Kumar, Accession no: ALCKP 46, 12 - 8- 2017.

\section{Flammulina velutipes (Curtis) Singer}

Fruiting body 1.5 - $7.8 \mathrm{~cm}$; convex, moist and sticky when fresh; bald when old; yellowish brown, often fading with maturity (Fig. 1-E); Hymenium surface narrowly attached to the stem; light yellow; crowded. Stalk is larger at base; tough; yellowish brown when young; dark brown to blackish velvety coating at maturity, $2.7-11.6 \times 3.2-4.8 \mathrm{~cm}$ in size (Fig. 1-F). Context is whitish, thin, Basidiospores; smooth; elliptical; inamyloid, $6.34-9.5 \times 3.25-5.45 \mu \mathrm{m}$ in size. Pleurocystidia absent; Cheilocystidia plenty, clavate, ventricose, thin-walled; 40.25 - 65.5 x 9.25 $13.86 \mu \mathrm{m}$ in size. Pileipellis anixolattice above a cutis; with branched, clamped, cylindrical hyphae, reddish brown in $\mathrm{KOH}$; terminal elements cylindrical; pileocystidia rare, fusoid-ventricose, brown colour in $\mathrm{KOH}$, often collapsing; No smell and taste.

\section{Collection examined}

On decomposing soil along with Bryophytes growing patch of Kondapalli forest, Andhra Pradesh, India. Collected by N. Praveen Kumar and Venkatesh Rampilla, Accession no: ALCKP 41, 12 - 8 - 2017.

It is identified by a sticky nature, orange-brown colour cap and dark, finely pubescent stalk. In coastal Northern California it is commonly seen at the base of senescent bush lupine (Lupinus arboreus) (18). The present study reveals that this fungal specimen is growing on decomposing soil along with some Bryophytes.

\section{Geastrum triplex Jungh.}

Fruit body large, fleshy epigeous, distinctly umbonate and onion-shaped; peristome fimbriate; hygroscopic; mycelial layer without radial splitting; with basal tuft of mycelium, not encrusted with debris collar usually present; spore-sac large, smooth. Expanded fruit body $2.8 \times 1.5 \mathrm{~cm}$ in size, splitting into $5-7$ rays; rays non-hygroscopic, arched, sometimes re-curved under the fruit body (Fig. 1-A). Mycelial layer persistent, at first pink, later yellowish brown, longitudinal splits large scales. Fibrous layer papery, pale grey-brown; Pseudo-parenchymatous layer fleshy, whitish, often darker with age and when dry, commonly splitting at the margin of the exoperidial disc and becoming raised into a conspicuous collar, hard and rather brittle when dry. Endoperidial body sessile, subglobose, sometimes depressed, without an apophysis, 25 - $42 \mathrm{~mm}$ diam. Endoperidium smooth, pale buff or clay. Peristome fibrillose, broadly 

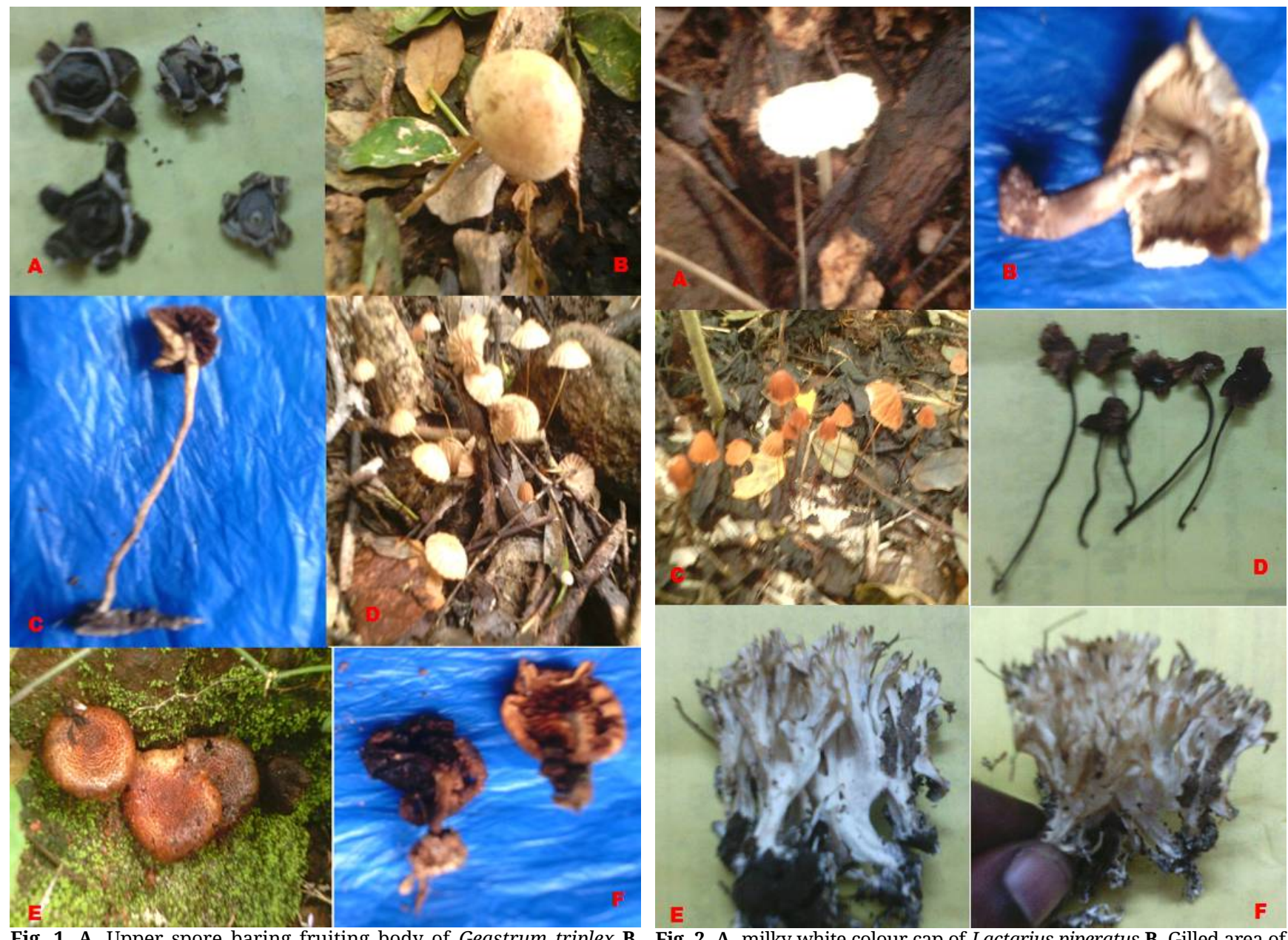

Fig. 1. A. Upper spore baring fruiting body of Geastrum triplex B. Fig. 2. A. milky white colour cap of Lactarius piperatus B. Gilled area of Upper surface of cap and stipe of Marasmius oreades C. Gill surface the Lactarius piperatus C. fruiting body of Marasmius fulvoferrugineus of Marasmius oreades D. Fruiting body of Marasmius siccus on leaf on leaf litter D. Dried specimen of Marasmius fulvoferrugineus E. litter E. Upper cap surface of Flammulina velutipes, F. The gilled fruiting body of Artomyces microsporus mushroom on soil F. Branching area of Flammulina velutipes, pattern of Artomyces microsporus mushroom.
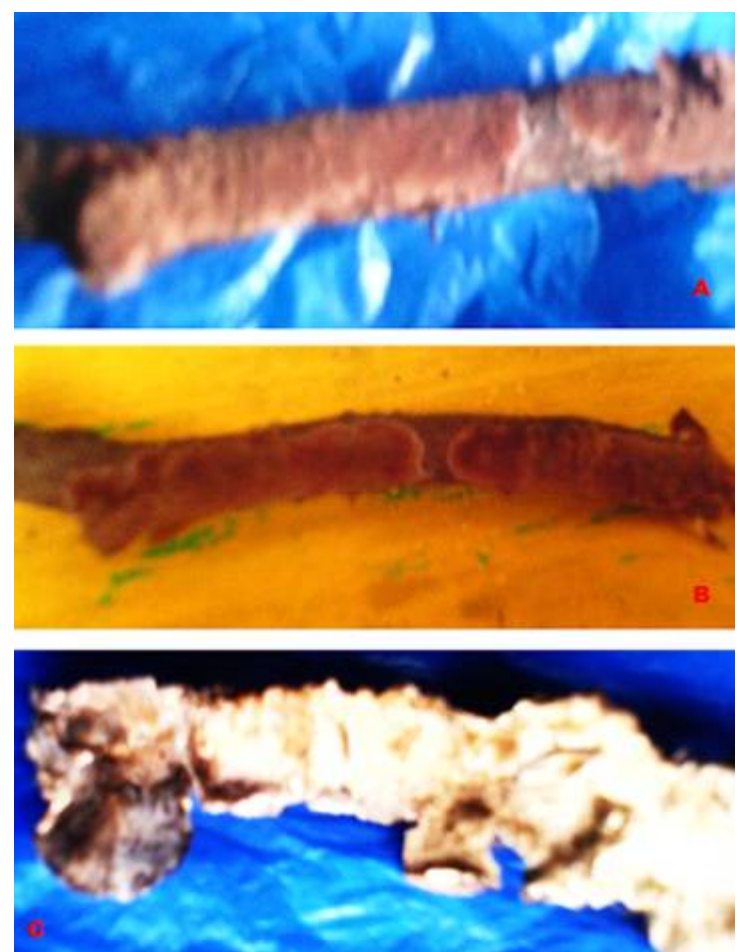

Fig. 3. A. Resupinate surface of Hymenochaetopsis rigidula B. Pore surface of Hymenochaetopsis rigidula attached to dead wood C. Resupinate surface of Bjerkandera adusta forming sporophore. 
conical, usually fairly distinct, delimited by a faint circular depression. Columella whitish, narrowly clavate. Mature gleba dark brown, without purple tint. Basidia not seen. Capillitial hyphae 3.56 - 7.86 $\mu \mathrm{m}$ diam., pale yellow-brown, gradually tapered, subacute tips, thick-walled, distinctly encrusted over much of their length. Basidiospores globose, dark brown, verruculose, $3.8-4.65 \mu \mathrm{m}$ diam. excluding ornament, $4.56-6.25 \mu \mathrm{m}$ diam. including ornament, verruculae mostly isolated, blunt-cylindric, $0.8-1.25$ $\mu \mathrm{m}$ high, $0.6-1.56 \mu \mathrm{m}$ across.

\section{Collection examined}

On humus, leafs litter and compost, in deciduous wood land area of Kondapalli forest, Andhra Pradesh, India. Collected by N. Praveen Kumar, Accession no: ALCKP 35, 12 - 8-2017.

G. triplex forms ectomycorrhizal with roots of Terminalia paniculata Roth. It was also found near the tree bases of Artocarpus heterophyllus Lam., Canarium strictum Roxb. and Mangifera indica L. G. triplex occurs in grasslands and moist-deciduous to Shola forests in Sasthanada, Kollam district, Kerala (19). It was also reported from the forest areas dominated by $T$. paniculata in Kuvempu University campus (Karnataka) (20). This Geaster was ectomycorrhizal with Shorea robusta Gaertn. in tropical moist deciduous forests of central India (21). Macro fungi from Mountains, Grassland and Forest areas of North Maharashtra reported fourteen species belonging to thirteen genera like $G$. triplex (22). In the present study, the wood inhabiting fungi was found to be growing on humus, leaf litter and compost, in deciduous wood land area of Kondapalli forest area.

Hymenochaetopsis rigidula (Berk. \& M. A. Curtis) S. H. He \& Jiao Yang, Mycol. Prog., 15: 1 8 (2016).

Fruiting body is effused, lightly elevated margins, coriaceous, brittle when dry, very thin, several centimeters in extent reflexed part short and broad attached to dead wood ( Fig. 3-A). Hymenium surface smooth, resupinate, tuberculate, slightly irregularly cracked, brown in young, grayish brown with age, margin distinct (Fig. 3-B). Hyphal system monomitic, generative hyphae without clamps, thin-walled, branched, Basidia clavate, 4 sterigmate, 17.1 x $3.9 \mu \mathrm{m}$ in diameter. Basidiospores cylindrical, slightly curved, $5.1 \times 1.5 \mu \mathrm{m}$ in size. Setal-hyphae, brownish $4.25-6.85 \mu \mathrm{m}$ in diameter. Setae dark brown, thickwalled, fusiform, $40.25-57.24 \mu \mathrm{m}$ in diameter.

\section{Collection examined}

On dead branch of hardwoods of Kondapalli forest, Andhra Pradesh, India. Collected by N. Praveen Kumar and Venkatesh Rampilla, Accession no: ALCKP 45, $12-8-2017$.

\section{Lactarius piperatus (L.) Pers.}

Fruiting body is broadly convex, flat, shallowly depressed, dry, the margin even; smooth; white colour in young, yellowish at maturity $4.9-15 \times 3.2-$ $4.5 \mathrm{~cm}$ in size (Fig. 2-A). Hymeni surface is gilled attached to the stem; very crowded; forking; pale ceramist colour. Stalk is thick, white, tapering at base; smooth; without potholes; solid, $2.8-8.7 \times 1.5-2.9$ $\mathrm{cm}$ in size (Fig. 2-B). Hyphal system is monomitic;
Context: white; thick; hard; yellowish at maturity. Milk: Copious; white colour; after exposure unchanging; not staining the white paper. With $\mathrm{KOH}$ pale magenta colour produced on cap surface. Basidiospores; broadly ellipsoid; 5.52 - 10.65 x 5.25 $8.75 \mu \mathrm{m}$ in size. Pleuro-macro-cystidia is $70 \mu \mathrm{m}$ length; subcylindrical. Cheilocystidia are same. Pileipellis a hypho-epithelium with very thin cutislike layer on upper and cellular layer on lower. No distinctive smell; excruciatingly acrid taste.

\section{Collection examined}

On decomposing leafy litter soil of Kondapalli forest, Andhra Pradesh, India. Collected by N. Praveen Kumar, Accession no: ALCKP 40, 12 - 8- 2017.

The L. piperatus (L.) Pers. is an edible mushroom belong to Russulaceae found in sub-tropical semievergreen forests (23). In the present study this wood inhabiting fungi was found to be growing on decomposing leafy litter soil of Kondapalli forest.

\section{Marasmius fulvoferrugineus Gilliam}

Fruiting body campanulate, sulcate, subvelutinous reddish brown, disc deep, ferruginous, margin yellowish 8 - $12 \mathrm{~mm}$ diameter (Fig. 2-C). Upper surface cylindric, hyaline, typically thin-walled, rarely thick-walled, 15 - 20 x 6.34 - $8.75 \mu \mathrm{m}$; Hymenium surface distant lamellae, broad, light yellow. Stalk is terete, glabrous, shiny, brown, arising from a thick pad of yellow colored mycelium $45 \times 1$ $\mathrm{mm}$ in size (Fig. 2-D). Hyphal system monomitic; Context is interwoven; lamellar trama regular; hyphae cylindrical, non-gelatinous, smooth, hyaline, dextrinoid, thin-walled, clamped, 4.25 - $9.65 \mu \mathrm{m}$ diameter. cortical hyphae, cylindric, smooth, pale yellow in stipe apex, brown in stipe base, strongly dextrinoid, clamped, $2.57-6.25 \mu \mathrm{m}$ diameter; medullary hyphae, hyaline, dextrinoid, clamped, thin-walled, $3.25-12.65 \mu \mathrm{m}$ diameter. Stipe vesture absent, isolated siccus- type broom cells similar to those of the pileipellis, located on the stipe apex. Basidia, clavate, hyaline, $3.62-4.25$ x $6.56-9.25 \mu \mathrm{m}$ in size. Basidiospores, clavate, curved, hyaline, inamyloid, smooth 14.23 - 18.65 x $4.56-6.45 \mu \mathrm{m}$ in size. Apical setulae, irregularly cylindrical, verrucose, obtuse, solid, yellowish $2.56-6.58$ x $0.8-1.5 \mu \mathrm{m}$. Pileipellis hymeniform, mottled, siccus - type broom cells; Pleurocystidia absent. Cheilocystidia similar to the siccus type, pileipellis elements; Odor not distinctive and taste often mealy.

\section{Collection examined}

On humus to decomposing tree litter soil of Kondapalli forest, Andhra Pradesh, India. Collected by N. Praveen Kumar, Accession no: ALCKP 38, 12 - 8 $-2017$.

It is found growing either scattered or gregariously in mixed woods in the North- Eastern United States and adjacent Canada (24). It was found growing scattered on dicotyledonous leaf litter and fallen twigs in mixed forests of Jasrota Wildlife Sanctuary Jammu and Kashmir, at an altitude of 550 $\mathrm{m}$ (25). In the present study, this wood inhabiting fungi was found to be growing on humus to decomposing tree litter soil of Kondapalli forest. 
Marasmius oreades (Bolt.: Fries) Fries Epicr. Myc. 375. 1838.

Fruiting body bell-shaped with in rolled margin at first, broadly convex with an even margin, with slight central bump; dry; bald; white; changing color as it dries out; the margin faintly lined $2-7 \mathrm{~cm}$ in size (Fig. 1-B). Hymenium surface gilled attached to the stem; nearly distant; white. Stalk: equal; dry; tough, pliant; whitish, $3.4-9.5 \mathrm{~cm} \times 1.25-6.2 \mathrm{~mm}$ in size (Fig. 1-C). Hyphal system is monomitic; Context: Tough; whitish. Basidiospores; smooth, ellipsoid; inamyloid, $7.56-10.25 \times 4.24-6.25 \mu \mathrm{m}$ in size. Cystidia absent. Pileipellis hymeniform; terminal elements clavate, pyriform, cylindrical, hyaline. No odor and taste.

\section{Collection examined}

On decomposing litter soil of Kondapalli forest, Andhra Pradesh, India. Collected by N. Praveen Kumar, Accession no: ALCKP 39, 12 - 8- 2017.

\section{Marasmius siccus (Schweinitz) Fries}

Fruiting body is up to $2 \mathrm{~cm}$ across, orange-brown; hemispherical, radially flat at first and plicate; Stalk is wiry, darkening brown from the base up (Fig. 2-D); Basidiospores clavate, often curved, 17 - 24 x 3.25 $5.65 \mu \mathrm{m}$ in size, bitter to sweet taste.

\section{Collection examined}

On humus to leaf litter and compost soil of Kondapalli forest, Andhra Pradesh, India collected by N. Praveen Kumar, Accession no: ALCKP 36, 12 - 8 2017.

Macro-fungi from Mountains, Grassland and Forest areas of North Maharashtra reported fourteen species belonging to thirteen genera like $M$. siccus (22). In the present study, this wood inhabiting fungi was found growing on humus to leaf litter and compost soil of Kondapalli forest.

\section{Conclusion}

Wood inhabiting fungi that grow specifically on leaf litter, wood debris, humus rich soil of forest helps in biodegradation, recycling the nutrients and increase soil fertility. Fruiting bodies of fungi were collected partially dead trees, fallen wooden logs, leaf litter and decomposing humus rich soil of Kondapalli forest area, Central Eastern Ghats, India. Out of 50 wood inhabiting fungal samples collected, nine was identified up to species level belonging to 7 genera; i.e. G. triplex Jungh., $M$. siccus (Schweinitz) Fries, $M$. fulvoferrugineus Gilliam, M. oreades (Bolt.: Fries) Fries Epicr. L. piperatus (L.) Pers., F. velutipes (Curtis) Singer, A. microsporus (Qiu X. Wu \& R. H. Petersen) Lickey, $H$. rigidula (Berk. \& M. A. Curtis) S. H. He \& Jiao Yang, and, B. adusta (Willd.:Fr.) Karst. For the first time A. microsporus (Qiu X. Wu \& R. $\mathrm{H}$. Petersen), Lickey and $H$. rigidula (Berk. \& M. A. Curtis) S. H. He \& Jiao Yang., was reported from India. M. fulvoferrugineus Gilliam, was reported second time from India. All wood inhabiting fungi were new records to Kondapalli forest, Central Eastern Ghats, South India. These wood inhabiting fungi was helping the forest soil rich with nutrients and also increase the fertility of soil. These fungi were indirectly helping in increasing the flora of the forest.

\section{Acknowledgements}

The authors were thankful to the Principal, P. G. Vice Principal, Head, Department of Botany, Andhra Loyola College, Vijayawada for laboratory facilities, Prof. Arun Arya, Head, Department of Environmental Sciences, MSUB, Vadodara for the confirmation of fungal identification.

\section{Authors' contributions}

The author collected the samples, identified it based on the macroscopic and microscopic characters and taken the pictures for preparation of papers. The coauthor helped in recording ecological data collection and flora identification.

\section{Conflict of interests}

Authors do not have any conflict of interests to declare.

\section{References}

1. Lücking R, and Nelsen MP. Ediacarans, proto-lichens, lichenderived Penicillium. A critical reassessment of the evolution of lichenization in: Transformative Paleobotany (Eds.: Krings, M., Harper, C.J., Cúneo, N.R. and Rothwell,. G.W.) Academic Press, London, 551-90; 2018. https://doi.org/10.1016/B978-0-12-813012-4.00023-1

2. Tedersoo L, Bahram M, Põlme S, Kõljalg U et al., Fungal biogeography, Global diversity and geography of soil fungi. Science, 2014, 346 (6213):1256688

3. Ravichandra NG. Fundamentals of Plant Pathology. Phi Learning Pvt. Ltd., India. 2013; pp. 151-52.

4. Jayasiri SC, Hyde KD, Ariyawansa HA, Bhat J, et al., The faces of fungi database: fungal names linked with morphology, phylogeny and human impacts. Fungal Divers. 2015;74:3-18.

5. Promputtha I, Lumyong S, Vijaykrishna D, McKenzie EHC, Hyde KD, Jeewon RA. phylogenetic evaluation of whether endophytes become saprotrophs at host senescence. Microb Ecol. 2007;53:579-90. https://doi.org/10.1007/s00248-006-9117$\mathrm{X}$

6. Seif E, Leigh J, Liu Y, Roewer I, Forget L, Lang BF. Comparative mitochondrial genomics in Zygomycetes: bacteria-like RNase P RNAs, mobile elements and a close source of the group I intron invasion in angiosperms. Nucleic Acid Res. 2005;33:734-44. https://doi.org/10.1093/nar/gki199

7. Dentinger BTM, Gaya E, O’Brien H, Suz LM, Lachlan R, Díaz Valderrama JR, Koch RA, Aime MC. Tales from the crypt: genome mining from Fungarium specimens improves resolution of the mushroom tree of life. Biol J Linn Soc. 2016; 117(1):11-32. https ://doi.org/10.1111/bij.12553

8. Hawksworth LD. The magnitude of fungal diversity: the 1.5 million species estimate revisited. Mycolog Res. 2001. 105:1422-32. https://doi.org/10.1017/S0953756201004725

9. Hawksworth LD. Fungal diversity and its implications for genetic resource collections. Studies in Mycol. 2004;50:9-18.

10. Chander H, Thakur S, Sharma S. Investigations on diversity of wood inhabiting fungi in Sarkaghat Region of District Mandi, Himachal Pradesh, North-Western Himalaya J Biol Chem Chron. 2017;3(1):41-54. 
11. Rathod MM. A study on wood-decaying fungi from the forests of Western Maharashtra, India Int J Curr Microbiol App Sci. 2016;5(3):520-27. https://doi.org/10.20546/ijcmas.2016.503.061

12. Ţura D, Wasser SP, Zmitrovich IV. Wood-inhabiting fungi applied aspects in "Fungi: applications and Management strategies”, published by Taylor \& Francis Group, LLC, 2016.

13. Rajgopal MV Andhra Pradesh district gazetteers, Krishna district gazetteer. Government Secretariat Press, Hyderabad 1977.

14. Nagadesi PK, Phenotypical studies of lignicolous fungi from Kondapalli hill Central Eastern Ghats, South India. Indian Phytopathology. https://doi.org/10.1007/s42360-018-0090-3

2018;71:589-97.

15. Reddy KN, Trimurthulu G, Sudhakar Reddy C. Plants used by the ethnic peoples of Krishna district, Andhra Pradesh. Indian J Trad knowl. 2010;9(2):313-17.

16. Nagadesi PK, Bhavani J, Arya A New records of lignicolous fungi from Krishna District, Andhra Pradesh, India. Int Lett Nat Sci. 2014;12(1):55-69. https://doi.org/10.20546/ijcmas.2016.503.061

17. Ryvarden K. Genera of polypores-nomenclature and taxonomy. Synopsis Fungorum 5 Fungi flora, OSLO, 1991; p 363.

18. Desjardin DE, Wood MG, Stevens FA. California mushrooms: The comprehensive identification guide. Timber Press: Portland, OR. 2015; p 560.

19. Mohanan C. Macro-fungi of Kerala. Kerala Forest Research Institute handbook \# 27. Peechi: Kerala Forest Research Institute; 2011.

20. Chittaragi A, Naika R, Ashwani HS, Nagaraj K. Antibacterial potential of Geastrum triplex Jungh. against plant and human pathogens. International Journal of Pharmtech Research. 2013;5:1456-64.
21. Sharma R, Rajak RC, Pandy AK. Ecto-mycorrhizal mushrooms in Indian tropical forests. Biodiversity. 2009;10:25-30. http:// dx.doi.org/10.1080/14888386.2009. 9712634

22. Patil SY. Diversity of Macro-fungi from North MaharashtraJournal of Emerging Technologies and Innovative Research. 2019;6(3):302-10.

23. Ao T, Deb CR, Khruomo N. Wild Edible Mushrooms of Nagaland, India: A potential food resource. J Experi Bio and Agricult Sci. 2016;4(1):59-65. https://doi.org/10.18006/2015.4(1).59.65

24. Gilliam MS. The genus in the northeastern United States and adjacent Canada. Mycotaxon. 1976;4(6):1-144.

25. Kaur M, Gupta A. New records of genus Marasmius (Marasmiaceae) from India. Kavaka. 2019;53:92-95. https:// doi.org/10.36460/Kavaka/53/2019/92-95

\section{Additional information}

Peer review information: Plant Science Today thanks Sectional Editor and the other anonymous reviewers for their contribution to the peer review of this work.

Reprints and permissions information is available at

https://horizonepublishing.com/journals/index.php/PST/open_access_policy

Publisher's Note: Horizon e-Publishing Group remains neutral with regard to jurisdictional claims in published maps and institutional affiliations.

To cite this article: Nagadesi P K, Rampilla V. New records of wood inhabiting fungi species from Kondapalli reserved forest of Central-Eastern Ghats, India. Plant Science Today. 2021;8(3):693-698.

https://doi.org/10.14719/pst.2021.8.3.1150

Plant Science Today, published by Horizon e-Publishing Group, is covered by Scopus, Web of Science, BIOSIS Previews, Clarivate Analytics, etc. See https://horizonepublishing.com/journals/index.php/PST/indexing_abstracting 